Jana S. Rošker

\title{
Antične ideje za sodobne družbe? Globalizacija konfucijanstva
}

Pričujoča številka revije Ars \& Humanitas obravnava razvoj konfucijanstva v Vzhodni Aziji in v svetu. Osredotočena je na vprašanja, povezana z etičnimi in filozofskimi osnovami konfucijanske modernizacije in $\mathrm{z}$ raziskavami, ki obravnavajo te osnove.

Osrednji del te številke bralstvu ponuja uvid v idejne temelje tega filozofskega in politično-etičnega sistema, ki so v 4. stoletju pred našim štetjem nastali na Kitajskem in se v naslednjih dveh tisočletjih razširili v druge regije Vzhodne Azije. V tem kontekstu nazorno prikaže osrednje elemente tega izvorno antičnega idejnega sistema, ki predstavlja temeljno kulturno izročilo, skupno vsem trem osrednjim vzhodnoazijskim regijam, pri čemer se osredotoča na kitajske in japonske razvoje.

Pomemben vidik, na katerega se osredotoča ta številka revije Ars \& Humanitas, je vprašanje univerzalnosti oziroma kulturne pogojenosti modernizacije. Webrova teza, po kateri protestantska etika (ali z njo primerljivi diskurzi, temelječi na monoteističnih religijah) predstavlja edino primerno osnovo za nastanek in razvoj modernizacije, je bila postavljena pod vprašaj z bliskovitim ekonomskim razvojem »štirih azijskih tigrov« in v zadnjem desetletju tudi z eksplozivno modernizacijo Ljudske republike Kitajske. Prispevki namreč izhajajo iz predpostavke, po kateri ni slučaj, da vse te regije, ki so bile priča tovrstni modernizaciji, sodijo v območje konfucijanskega kulturnega izročila.

Zato vsebuje pisano paleto prispevkov, ki ponujajo pregled zgodovine konfucijanstva in njegove širitve iz Kitajske, vkateri je nastalo, v druge regije Vzhodne Azije ter vsebinske razvoje te osrednje vzhodnoazijske idejne dediščine. Konceptualna zasnova številke pa je zastavljena še širše, saj izhaja iz predpostavke, po kateri lahko osnove konfucijanske etike služijo tudi kot izhodišče takšnih modelov modernizacije, ki ne temeljijo nujno na postulatu individualizma, temveč na modelu komunitarizma. Zato ni slučaj, da osnove konfucijanske etike $\mathrm{v}$ zadnjih letih prihajajo vse bolj v središče pozornosti akademskih krogov zunaj Vzhodne Azije. To ne velja samo za evropske in severnoameriške regije, kjer so raziskave konfucijanstva že zelo dobro razvite, temveč tudi za številne manj razvite družbe, ki iščejo nove poti usklajevanja specifike lastnih tradicij z zasnovami "drugačnih", neevropskih modelov modernizacije. Zato pomemben del pričujoče številke tvori tudi sklop o razvoju konfucijanskih študij v Latinski Ameriki, ki postaja vse bolj relevanten dejavnik na odru mednarodnih odnosov. 
Vsebinska rdeča nit pričujoče publikacije je prikaz skupnih točk in lokalnih razlik v dojemanju konfucijanske filozofije; vrsta člankov analizira tudi njen vpliv na politične in državne institucije obravnavanih regij. Zato ta številka Ars \& Humanitas predstavlja pomembno osnovo za ozaveščanje kontekstualnih in konceptualnih povezav med različnimi državami Vzhodne Azije, kajti prav te povezave so pomemben temelj širitve posodobljenih elementov konfucijanskega nauka na mednarodno raven.

Pri tem želimo pri bralstvu ozavestiti dejstvo, da konfucijanstvo ni zgolj filozofska, temveč tudi in predvsem politična teorija, ki je poldrugo tisočletje nadvse tvorno sooblikovala vse osrednje državne in socialne institucije Vzhodne Azije. Bralkam in bralcem bo pričujoča številka revije ponudila tudi uvid v tradicionalne elemente, ki zakoličujejo in sooblikujejo sodobne vzhodnoazijske družbe, zlasti prek prikaza vidikov, skozi katere lahko spoznamo latentni vpliv konfucijanskih ideologij $\mathrm{v}$ modernih državah Vzhodne Azije. Pomemben del pričujoče številke namreč obravnava tudi specifike vzhodnoazijske modernizacije, ki je ne gre povsem enačiti s pozahodenjem, temveč je delno kulturno opredeljena.

Pri ustvarjanju pričujoče revije smo bili še posebej pozorni na probleme, povezane $\mathrm{z}$ obravnavanjem medkulturnih vidikov modernizacije ter njene ideologije in miselnosti. Pri teh vprašanjih namreč ne gre zgolj za probleme filozofsko-konceptualne narave. $V$ tem smislu je prav tako pomemben tudi geopolitični vidik naše razprave; pri analizi sporočilnosti vsake družbeno relevantne idejne struje je namreč pomembno upoštevati tudi ekonomski in zgodovinski kontekst, znotraj katerega se je razvila. Konfucijanstvo in njegov sodobni preporod pri tem nista nikakršni izjemi. Upoštevati moramo namreč dejstvo, da je transnacionalizacija kapitala med drugim povzročila tudi univerzalizacijo kapitalističnega načina proizvodnje, ki je s tem postal oddvojen od svojega specifičnega zgodovinskega izvora, tj. Evrope. $Z$ drugimi besedami: navaditi se moramo na dejstvo, da »zgodba kapitalizma« ni več samo »evropska zgodba«.

Številni teoretiki menijo, da prevlada »multikulturalizma» hkrati pomeni konec evrocentrizma. A prav zaradi tega je pojem multikulturalizma zavajajoč, saj ne prekriva zgolj kulturne fragmentacije, do katere prihaja v obdobju globalizacije, temveč hkrati v enaki meri spodkopava tradicionalne oblike proizvodnje in socialnih omrežij. Zato je konec evrocentrizma iluzoren, saj ostaja njegova notranja struktura še vedno prevladujoči del idejne konstelacije postmodernih globaliziranih družb. Pri tem niti ne gre toliko za fragmentacijo kultur, temveč bolj za fragmentacijo prostora, ki globalnemu kapitalizmu ponuja nove možnosti reševanja starih problemov, povezanih z maksimiranjem dobička, nadzorovanjem trga ter osvobajanjem proizvodnje in marketinga izpod pritiskov možnih socialnih intervencij (povezanost delavskih stavk) ali političnega nadzora (državni ukrepi). Ta fragmentacija prostora pa skupaj 
s prikritim ohranjanjem latentnega evrocentrizma implicira fragmentacijo časovnih dimenzij kapitalizma. In ne samo to: fragmentacija prostora zaobjema tudi razbitost socialnega položaja posameznika, ki se, kot opozarjajo predstavniki sodobnega konfucijanstva, manifestira v odtujenosti modernega subjekta.

Pretirano osredotočanje na evrocentrizem ter njegove idejne in politične konotacije pa lahko po drugi strani našo pozornost odvrne od omenjene fragmentacije sveta na drugačen, prav tako pomemben način. Modernizacija ima namreč povsod številne in nadvse kompleksne posledice. Zagotovo ni slučaj, katere vidike bomo pri tem izbirali kot predmet obravnave. Enodimenzionalna kritika evrocentrizma ter njegovega zgodovinopisja in strukturiranja sveta pri tem ne zadošča. V svojem najširšem pomenu, torej vključujoč tudi vsakodnevne življenjske prakse, evrocentrizem že dolgo ni več zgolj stvar Evrope, temveč pojav globalne modernosti; izzivi evrocentrizma zato vplivajo tudi na tiste neevropske družbe, ki so modernizacijo že zdavnaj sprejele kot svoje vodilno načelo. $\mathrm{V}$ tem smislu sodijo teorije sodobnih konfucijancev v kontekst »preporoda vzhodnoazijske zgodovine«, ki v brzicah eksplozivno »vsiljene« modernizacije sploh ni prišla do besede. Vse to se lepo sklada $\mathrm{z}$ aktualno »reinkarnacijo « teorij modernosti, ki išče možnosti absorbiranja multikulturnih, alternativnih obrazov modernizacije. Ta odvrnitev od evrocentrizma, ki je bila v kolonializmu (in pred njim) lastna klasičnim teorijam modernizacije, pa je zgolj navidezna, saj se dogaja na skupni osnovi globaliziranega kapitalizma. V tej fazi globalnega razvoja je popolnoma samoumevno in celo potrebno, da se v diskurze modernizacije vključijo tudi vse prej omalovaževane »kulturne inačice« modernizacije, ki so bile poprej razglašene za njene »ovire«. Inkorporacija in ponotranjenje različnih »repertoarjev modernizacije« (vključno $\mathrm{z}$ njihovimi specifičnimi vrednotami ter mehanizmi proizvodnje in potrošništva) $v$ ekonomske prakse sodobnega globalnega sistema potemtakem služi tudi kot gonilna sila univerzalizacije institucionalnih struktur, ki so potrebne za njegovo delovanje.

Vse to lepo sovpada z novimi, postmodernimi koncepti, kamor sodi, denimo, koncept »raznovrstnih modernosti «(multiple modernities) Shmuela Noaha Eisenstadta. Četudi je vzpostavitev tega koncepta osnovana na tezi, po kateri modernizacija neevropskih družb ni enaka njihovemu pozahodenju, so sodobne zahodne teorije modernizacije v svojem bistvu konservativne, saj svoje interpretacije različnih oblik modernizacije in modernosti postavljajo $\mathrm{v}$ kontekst afirmacije globalnih razmerij oblasti, pri čemer njene različne modele umeščajo v okvire različnih držav, narodov in »kultur«, ki so videne kot njihova razločevalna posebnost.

Zato je ta številka revije Ars \& Humanitas pomemben korak v ozaveščanju dejstva, da razlike med sedanjostjo in preteklostjo v prvi vrsti ne gre iskati samo v izzivih evrocentrizma s strani različnih kulturnih perspektiv, temveč tudi v priznavanju 
dejstva, da je klasični model modernizacije na globalni ravni privedel do situacije, v kateri problemi, ki jih prinaša, niso več zgolj problemi t. i. »neevropskih «, temveč tudi evroameriških družb. Potreba po spoznavanju »alternativnih modernosti« torej predstavlja izziv tudi za evroameriške kulture modernizacij, saj na novo vzpostavlja njihove meje oziroma samo lokaliziranje modernosti kot take.

Prispevki, ki so zbrani v tej številki, obravnavajo različne sodobne poglede na konfucijanstvo in konfucianizem ${ }^{1}$ ter poskušajo - vsak na svoj način - razkriti del posebnega rezervoarja vrednot in znanj, ki lahko nedvomno predstavljajo obogatitev naših predpostavk o različnosti tradicij in modernosti. Vendar pri tem ne smemo pozabiti, da živimo v obdobju, ki ni opredeljeno zgolj s poskusi oživitev različnih tradicij, temveč tudi s poskusi njihovega usklajevanja s potrebami prevladujočih ekonomskih, političnih in aksioloških struktur globalnega sveta. Afirmacija modernosti kot palete življenjskih stilov in sovpadajočih vrednot tvori namreč nedvoumno predpostavko domala vseh sodobnih konfucijanskih diskurzov.

Pri vrednotenju modernih konfucijanskih poskusov vzpostavitve »specifično kitajskih« idejnih osnov modernizacije nam je bilo pomembno, da smo jih skušali razumevati tudi znotraj konteksta vprašanj, povezanih s Hobsbawmovo predpostavko "zamišljenih tradicij« (invented traditions). Pri tem gre za vprašanji, v kolikšni meri te idejne »tradicije« dejansko temeljijo na zgodovinskih predpostavkah in v kolikšni meri so zgolj proizvod (ideoloških in političnih) zahtev sodobnega časa. Toliko bolj pomembno je tudi poznavanje dejanskih osnov klasičnega konfucijanskega nauka; zato se vrsta prispevkov, ki so vključeni v pričujočo številko, posveča analizi pomembnih elementov teh osnov in razjasnitvi predsodkov o despotski naravi konfucijanstva, ki še vedno prevladujejo $\mathrm{v}$ javnosti.

Za evropske raziskovalce in raziskovalke so raziskave neevropskih kultur vselej povezane s problemi različnih jezikov, tradicij, zgodovin in socializacijskih procesov. Prispevki v tej številki izhajajo iz predpostavke, po kateri je zahodna epistemologija samo eden od številnih modelov človeškega spoznavanja stvarnosti, zato temeljijo na osrednjih metodoloških načelih medkulturnih raziskav. To pomeni, da upoštevajo vzajemno nesoizmerljivost različnih kulturno pogojenih paradigem. Pri tem gre tudi za upoštevanje specifičnih teoretskih okvirov, ki so nastali v različno strukturiranih diskurzih različnih kulturnih in jezikovnih okolij. Uporabljene metode so znotraj osnovnega teoretskega ogrodja usmerjene $\mathrm{v}$ sestavo interdisciplinarnih perspektiv, znanj, relacij in epistemologij, ki sodijo na področja sociologije, filozofije in politične

1 Pri tem gre za dva različna diskurza. Medtem ko termin konfucijanstvo označuje izvorni nauk in njegove filozofske razvoje, se izraz konfucianizem nanaša na državno doktrino in državotvorno ideologijo, ki je na Kitajskem prevladovala od 2. do začetka 20. stoletja. Slednja se sicer sklicuje na konfucijanski nauk, vendar v resnici vsebuje zelo veliko elementov legalistične doktrine. 
teorije. Ta pristop nam je omogočil tudi bolj ali manj koherenten prikaz tematik, ki jih ni mogoče konsistentno dojeti $\mathrm{z}$ enega samega, partikularnega vidika.

Številka je zato znotraj širšega področja kulturologije interdisciplinarno zasnovana in vključuje perspektive oziroma ustrezne raziskovalne metode, ki sodijo $\mathrm{v}$ pet vsebinskih sklopov; v vsakem od njih so zbrani prispevki, ki obravnavajo vsebinsko sorodne probleme tradicionalnega in/ali sodobnega konfucijanstva.

Prvi sklop z naslovom Sodobna Kitajska, preporod konfucijanstva in kitajske "nacionalne študije " problematizira t. i. sodobni konfucijanski preporod, ki se je v zadnjih desetletjih pričel eksplozivno širiti v Ljudski republiki Kitajski. Prispevka, ki sta objavljena $\mathrm{v}$ tem prvem sklopu, obravnavata ideologizacijo konfucianizma in prikazujeta večplastno zlorabo izvornega nauka, ki naj bi v tem spolitiziranem in populariziranem kontekstu služil kot ideološko vezivo sodobne kitajske družbe. Kot pokažeta avtor in avtorica obeh prispevkov tega vsebinskega sklopa, tovrstne manipulacije »konfucijanstva« služijo kot ideološka podpora takšnemu modelu zakonodaje in nove družbene etike, ki se uporablja kot orodje discipliniranja in moraliziranja s ciljem ohranjanja vladajočega režima. Zato vzpostavljajo in uporabljajo tudi simbol takšnega Konfucija, ki naj bi predstavljal in razširjal "pravilno« moralo, ki naj bi se kazala v podrejenosti posameznika "višjim» družbenim ciljem in v brezpogojni poslušnosti nadrejenim. Raoul David Findeisen, ki je avtor prvega članka $v$ tem uvodnem sklopu, obravnava problematiko t. i. »nacionalnih študij« oziroma Guoxue. V prispevku z naslovom »Kaj je Guoxue? - vzorci organizacije znanja na primeru dveh 'slovarjev' (2009 in 2014) « pokaže, da lahko ta preporod tradicije vidimo kot obrambno reakcijo na spremembo družbenih in političnih paradigem. Te spremembe opredeljujejo sodobni pritiski, povezani z nadvlado (zahodne) znanosti in tehnologije, ki se je vzpostavila v poznem 19. stoletju in je prevladala $\mathrm{v}$ zadnjih dveh desetletjih 20. stoletja. Avtor osvetli dejstvo, da so Guoxue kot zakladnica domnevne tradicije torej ideološki konstrukt in sredstvo legitimacije vladajočega režima. Drugi članek v tem sklopu nosi naslov »'Skrivanje sijaja' - vzpon in zaton konfucijanske zunanje politike« in je nastal pod peresom Helene Motoh. Avtorica v njem analizira razvoj novega modela kitajske kulturne diplomacije, ki se je pričel vzpostavljati pred dobrim desetletjem in je bil utemeljen v neotradicionalističnem ideološkem okviru sodobnega konfucijanskega preporoda. Članek prikaže, zakaj in na kakšen način je bilo eksplozivno širjenje institucij kitajske kulturne diplomacije prikazano kot možnost novega in bolj poglobljenega medkulturnega dialoga, ter problematizira negotovost tujine glede njenih dejanskih političnih vsebin in ciljev. Za razliko od običajnih interpretacij sodobne kitajske »mehke oblasti « se avtorica v svojem prispevku ne ukvarja toliko s konkretnimi vprašanji (ne)uspeha kulturne diplomacije Ljudske republike Kitajske, temveč se bolj osredotoča na širše kontekste njenih zunanjepolitičnih strategij. 
Drugi vsebinski sklop je posvečen preteklim in sodobnim razvojem konfucijanstva oziroma konfucianizma na Japonskem. V uvodnem prispevku Marko Ogrizek pojasni nekatere temeljne posebnosti modifikacije in specifičnih nadgradenj kitajske neokonfucijanske filozofije, do katerih je prišlo potem, ko se je ta pričela širiti v japonski kulturno-jezikovni regiji. Prispevek z naslovom »Pojmi poti, kreposti in dobrega v konfucijanskih naukih Itôja Jinsaija in Ogyûja Soraija « analizira te vsebinske in konceptualne razvoje na primeru dela dveh pomembnih japonskih neokonfucijanskih filozofov 17. stoletja. Avtor nazorno prikaže, da Itô Jinsai v svojih esejih sledi izvornemu mencijanskemu nauku, ki izhaja iz vidika občega dobrega, poti neba ter človekovih naravnih moralnih zmožnosti, medtem ko Ogyû Sorai nastopi kot njegov radikalen kritik, ki osrednje pojme konfucijanske filozofije podredi celoviti politizaciji. S tem je Sorai postavil idejne temelje za razvoj državotvornih elementov japonskega konfucianizma, ki jih v svojih prispevkih obravnavata Nataša Visočnik (»Vloga konfucijanske ideologije pri oblikovanju nacionalne države na Japonskem«) in Luka Culiberg (»Tradicija, modernost in vloga konfucianizma pri izgradnji japonske nacionalne države«). Članek Nataše Visočnik je posvečen procesom konstituiranja nacionalnih in kulturnih identitet japonskih državljanov in državljank ter pokaže, zakaj so bili ti procesi še posebej intenzivni v obdobju Meiji (1868-1912), ko se je Japonska odprla svetu in je poskusila oblikovati nacionalno državo. $\mathrm{V}$ tem okviru modernizacije japonske države avtorica obravnava tudi preporod konfucijanstva in pokaže, da je v tem kontekstu igral zelo pomembno vlogo. Do preporoda je prvič prišlo že takoj po obdobju Meiji, ko so konfucijanstvo delno pomešali s posodobljenim šintoizmom. Ta preporod se je pospešil na začetku 20. stoletja, ko je postalo jasno, da med državljani in državljankami upadajo tradicionalne vrline poslušne zvestobe, ter se je pokazala potreba po oživljanju tradicije v službi modernih ideologij. Na tem ozadju postane veliko bolj jasno, zakaj je bil konfucianizem naposled vključen v japonsko »nacionalno politiko« in je postal sestavni del »nacionalnega bistva « ter simbol »nacionalnih tradicij«. Tudi Luka Culiberg v svojem prispevku sledi razvoju konfucijanske misli na Japonskem in pokaže, kako je konfucianizem s svojim osrednjim konceptom poti ostal idejni temelj japonskih intelektualnih krogov. Avtor pa pri tem opozori na dejstvo, da je japonski konfucianizem pri tem doživel številne transformacije in reinterpretacije, ki jih ponazori na primeru treh šol, namreč kogaku, kokugaku in rangaku. Nova nacionalna država, ki so jo vzpostavili revolucionarji v obdobju Meiji, je na vsebinski ravni postala prav zmes omenjenih idejnih smeri. Na ta način Culiberg prikaže temeljni ustroj mejdžijevske države, ki je bila po eni strani moderna, industrijska in tehnološko napredna tvorba, po drugi strani pa je v svojem institucionalnem ogrodju temeljila na trdni konfucianistični ideologiji.

Tretji vsebinski sklop z naslovom Konfucijanska morala in njene implikacije je posvečen moralno-etičnim prvinam konfucijanskega nauka in njegovim ideološkim 
transformacijam. Andrej Ule se v svojem prispevku »Pomen konfucijanske misli za ohranjanje človečnosti in razumnosti v sodobnem svetu « ukvarja $\mathrm{z}$ možnostmi sinteze človečnosti in racionalnosti v postmodernih družbah. Avtor se sprašuje, ali in na kakšen način nam $\mathrm{v}$ moralnih dilemah sodobnega sveta lahko pomaga kitajska filozofska misel in zlasti konfucijanska tradicija. Ugotavlja, da je bila racionalnost v kitajski filozofski tradiciji večinoma dojeta kot sposobnost človeške »srčne zavesti « (xin) za modro razmišljanje, pametno razpravljanje in ravnanje, ki je v skladu z najvišjimi vrlinami plemenitega človeka. Avtor izpostavi, da je takšno razumevanje racionalnosti bolj podobno konceptu celostne razumnosti kot pa racionalnosti v zahodni filozofski tradiciji. Razumnost $\mathrm{v}$ kontekstu kitajske kulture, zlasti konfucijanstva, je močno vezana na specifične oblike argumentacije, predvsem na sklepanje po analogiji, uporabo metafor in vzorčnih modelov vedenja, ki se ne dajo stlačiti v okvire logične (deduktivne ali induktivne) argumentacije. Pomemben vidik je, kot prikaže avtor, $\mathrm{v}$ konfucijanskih možnostih povezave med samointeresi posameznika in njegovo moralnostjo. Članek osvetli tudi dejstvo, da sodobni človek potrebuje prav takšno prakso, če naj pridobi širše in globlje pojmovanje človečnosti in razumnosti. Prispevek Nataše Vampelj Suhadolnik »Mao Zedong kot poslednji konfucijanski vladar? Moralno-didaktični vidik konfucijanske umetnosti« ideologizacijo konfucianistične morale obravnava skozi prizmo moderne kitajske umetnosti. Prispevek se osredotoča na problematiko moralno-didaktičnega vidika »konfucijanske« umetnosti, ki nastopa v obliki t. i. narativnega slikarstva. Avtorica prikaže, da so številni tradicionalni vladarji z namenom legitimacije politične avtoritete s pomočjo vizualnega medija promovirali konfucijanske družbene in politične vrednote, kar naj bi jih prikazalo kot idealne konfucijanske vladarje. Izhajajoč iz teh tradicionalnih primerov avtorica $\mathrm{v}$ drugem delu članka interpretira slikovno propagando prvega predsednika komunistične stranke Kitajske Mao Zedonga, ki je ravno tako s pomočjo didaktičnih ilustracij v obliki propagandnih plakatov širil moderne prvine komunistične ideologije. Avtorica skozi kontrastivno analizo pokaže, da je pri tem pogosto (četudi na latenten in prikrit način) sledil tradicionalnemu modelu »konfucijanskega vladarja «, čeravno ga je ovil v simbolne tančice modernih ideologij 20. stoletja.

Predzadnji sklop Epistemološke osnove konfucijanskega nauka: zaskrbljena zavest, razum in intuicija obravnava teoretske in konceptualne osnove dojemanja ter interpretacije stvarnosti znotraj konfucijanskega nauka in njihove implikacije v okvirih t. i. modernega konfucijanstva. Pri tem se osredotoča predvsem na izsledke njegove »druge generacije«, ki je živela in delovala na Tajvanu v drugi polovici 20. stoletja. Članek Jane S. Rošker z naslovom »Epistemologija modernega konfucijanstva na primeru druge generacije - med razumom in intuicijo« obravnava epistemološke teorije vseh osrednjih predstavnikov te intelektualne struje. Ker so si prizadevali za vzpostavitev 
sinteze med lastno miselno tradicijo in evropskimi teoretskimi sistemi oziroma za posodobitev te tradicije in njeno prilagoditev razmeram modernih družb, so tudi $\mathrm{v}$ svojih epistemoloških diskurzih izhajali iz specifičnih posebnosti tradicionalne kitajske epistemološke miselnosti. Avtorica izpostavi, da je znanje v okviru prevladujočih evropskih epistemologij dojeto kot nekaj, kar se pridobiva s pomočjo mišljenja, kar pomeni, da je osnovano na znanstvenem videnju sveta. $\mathrm{V}$ tradicionalni kitajski miselnosti pa se je to vprašanje razumevalo $v$ veliko širšem smislu; znanje je bilo $v$ tem okviru nekaj, kar je (v prvi vrsti) povezano tudi z moralnimi vsebinami in česar ni mogoče ločevati od (družbene) prakse. Téa Sernelj se v svojem članku »Xu Fuguanova študija osnega obdobja na Kitajskem in koncept zaskrbljene zavesti« posveča izsledkom enega najvidnejših predstavnikov zgoraj omenjene »druge generacije«, namreč tajvanskega filozofa in esejista Xu Fuguana, ki je zunaj Kitajske še precej neraziskan. Vendar je njegov koncept »zaskrbljenosti« (youhuan yishi) izjemno pomemben ne samo za teoretsko razjasnitev posebnih značilnosti, ki določajo ideološko (in s tem tudi politično) strukturo antične kitajske družbe, temveč tudi za medkulturno nadgradnjo Jaspersove teorije "osnega obdobja«. Avtorica podrobno predstavi ta koncept in hkrati izdela analizo njegove povezave $\mathrm{z}$ moderno konfucijansko hipotezo o odsotnosti zunanjega Boga (ali božanstev) v tradicionalni kitajski kulturi.

Poslednji vsebinski sklop z naslovom Konfucijev Dolgi pohod: razvoj konfucijanskih študij $v$ Latinski Ameriki je posvečen širitvi elementov konfucijanskega nauka $\mathrm{v}$ novonastajajočih sinoloških disciplinah Latinske Amerike. Sklop je posvečen razmisleku o tem, kako lahko prvine konfucijanske filozofije in politične teorije prispevajo k prestrukturiranju držav v razvoju, ki lovijo ravnotežje na ozki brvi med pritiski sodobnega globalnega kapitalizma in dediščinami lastnih tradicij. Novo zanimanje teoretikov in teoretičark te regije za konfucijanski preporod morda kaže na to, da je lahko specifika vzhodnoazijskih tipov modernizacije in racionalizacije sveta, ob upoštevanju lastnih idejnih tradicij, $\mathrm{v}$ marsikaterem pogledu model za podobne razvoje izven geopolitičnega območja Kitajske ali Vzhodne Azije. Zato ni slučaj, da ima prvi prispevek tega sklopa, ki ga je napisal brazilski sinolog André Bueno, naslov »Razumeti 'novi konfucianizem': ponovno odkrivanje konfucianizma in prihodnost Kitajske«. Avtor v njem analizira idejno in ideološko ozadje sodobnega konfucianizma in se v njegovi luči sprašuje o možnostih novih političnih opcij za bodočo družbenopolitično ureditev Kitajske. Izhajajoč iz analize Jiang Qingovega sodobnega modela konfucijanske družbene ureditve Bueno izpostavi vse večjo in vse globljo diskrepanco med ekonomsko evolucijo kitajske države na eni ter marksističnimi diskurzi in idejami na drugi strani. Avtor ugotavlja, da je konfucijanski preporod pravzaprav pomemben del družbene tranzicije, ki bi lahko privedla od ortodoksno »komunistične« vlade do novega tipa družbene in politične ureditve, ki bi bila osnovana na prenovi tradicionalnih 
kitajskih vrednot. Kot rečeno, je ta paradigma lahko zanimiva za iskanje novih, drugačnih modelov modernosti tudi znotraj latinskoameriških družb. V drugem prispevku tega sklopa $\mathrm{z}$ naslovom »Od Mehike do Brazilije, od starodavne Kitajske do novega konfucianizma: sinološke študije v Latinski Ameriki« poskuša Barbara Pihler Ciglič to vprašanje osvetliti s prikazom razvoja konfucijanskih študij v latinskoameriški sinologiji. Izpostavi osrednje premise razvoja sinologije na geografsko, politično in kulturno zelo raznolikem področju Latinske Amerike ter natančneje predstavi situacijo $\mathrm{v}$ Mehiki, državi z najdaljšo sinološko tradicijo, ter v Braziliji, kjer je sinologija še na samem začetku, skozi prizmo raziskav dveh sinologov, Andréja Buena $\mathrm{z}$ univerze $\mathrm{v}$ Rio de Janeiro in Chen Yonga, ki predava sinologijo na osrednji mehiški univerzi $E l$ Colegio de México. Ta avtor se v svojih, v španščini napisanih raziskavah posveča predstavitvam konfucijanske filozofije latinskoameriškemu bralstvu ter odpravljanju posploševanj in predsodkov o njej. Skozi primerjalno analizo omenjenih študij Barbara Pihler Ciglič prikaže, da so tudi latinskoameriške raziskave konfucijanstva osredotočene na razumevanje obojega, tako antične kot tudi sodobne kitajske kulture, in da vselej znova izpostavljajo dejstvo, da kitajske modernizacije ni mogoče dojeti brez poznavanja in razumevanja njene preteklosti in njene bogate tradicije. Ta uvid je namreč izjemno pomemben tudi za prenovo in preporod lastnih idejnih in družbenih tradicij latinskoameriškega prostora.

Tematski sklop o konfucijanstvu, ki predstavlja osrednji del pričujoče številke revije Ars \& Humanitas, se zaključi z dvema recenzijama, najprej knjige Retrospektiva in perspektive raziskovanja vzhodnoazijskega konfucianizma, ki jo je uredil in izdal eden najvidnejših sodobnih tajvanskih strokovnjakov za moderno konfucijanstvo $\mathrm{v}$ Vzhodni Aziji Huang Chun-chieh, nato pa še prve monografije o Starodavni Kitajski v Braziliji, Antična branja: obrazi starodavne Kitajske (Antigas Leituras: Visơes da China Antiga), ki sta jo uredila André Bueno in José Maria Neto.

Upamo, da bo pričujoča številka Ars \& Humanitas zanimiva ne samo za sinologe in sinologinje, temveč tudi za širše kroge zainteresiranega bralstva. Avtorji in avtorice prispevkov, ki so zbrani v njej, so namreč nazorno pokazali, da lahko sodobno raziskovanje konfucianizma pomembno prispeva k vnovični vzpostavitvi lokalnih kulturnih identitet in k oblikovanju novih, moderniziranih podob ne zgolj vzhodnoazijske, temveč tudi svetovne kulturne dediščine. Zato smo prepričani, da pričujoča številka predstavlja pomemben korak na poti k tovrstni akademski analizi in razumevanju drugačnosti, saj nam lahko marsikaj pove o času in prostoru v katerem živimo, ter o sodobnem konfucijanstvu v vlogi ene najpomembnejših idejnih tradicij sodobnega sveta. Njegovi izsledki bodo v slovenskih filozofskih in kulturoloških diskurzih zagotovo prispevali $\mathrm{k}$ pridobivanju novih vpogledov $\mathrm{v}$ aktualno vlogo $\mathrm{t}$. $\mathrm{i}$. »nezahodnih« idejnih tradicij. 